\title{
Assessment of Fluid Intake Pattern in Anambra State, Southeast Nigeria
}

\author{
C. C. Ibeh, N. Jisike-Onuigbo, F. O. Emelumadu, C. Ifeadike, M. J. Umeh, C. E. Onah, \\ A. Mbanuzuru, D. Obi, C. N. Ogbuagu
}

\begin{abstract}
Background: Water is essential for life and accounts for about 70 percent of the human body fat-free mass. Daily loss of $2.5 \mathrm{~L}$ in temperate climate occurs on least minimal activity while exercises, rises in temperature, illnesses raise the fluid loss. Adequate intake of water is necessary for optimal body functions, development and health. Estimates of water intake shows wide variations depending on factors such as temperature, activity level, availability and accessibility of fluid, fluid type, packaging, and socio-cultural factors.

Context and purpose of study: Residents in the tropics are exposed to high temperatures and loss of excess fluid from perspiration and would expectedly require high fluid intake for normal body function. A cross sectional study was conducted in Aanmbra State, southeast Nigeria to assess the fluid intake of subjects. Two hundred and fifty people were selected by multistage sampling technique. They were drawn from employees in government secretariats, banks and artisans engaged in motor mechanic worksites. Using a semi-structured questionnaire, calibrated plastic cups, weighing scale and standiometer, the socio-demographic data, the 24-hour fluid intake, weight and height of the subjects were obtained.
\end{abstract}

Results: The mean age of the respondents was $36.6 \pm 11.5$ years. $60.1 \%$ (146) were males while $39.9 \%$ (97) were females. There were $130(53.5 \%)$ civil servants and $113(46.5 \%)$ artisans. The median 24 -hour fluid intake was $3.5 \mathrm{~L}$ with artisans having higher intake than the civil servants. $\left(\chi^{2}\right.$ $=16.57, \mathrm{df}=2, \mathrm{p}<0.05)$. The median fluid intake for males was 3.8 $\mathrm{L}$ compared with $3.1 \mathrm{~L}$ for females.

Main findings: Less than one quarter of the subjects met the respective WHO recommendations for males and females. About half $(47.9 \%)$ of the males and $39.2 \%$ of the females failed to meet the USA IOM recommendations.

Conclusions: The subjects drank less fluid than people in temperate climes and below international recommendations for moderate activities and for manual labour in high temperatures.

Brief summary and potential implications: Inadequate intake of fluid lead to reduced work/exercise performance, endanger

Published on June 22, 2020

Christian C. Ibeh, Nnamdi Azikiwe University Teaching Hospital Nnewi, Nigeria.

(corresponding e-mail: christiancibeh ${ }^{\circledR}$ yahoo.com).

N. Jisike-Onuigbo, Nnamdi Azikiwe University Teaching Hospital Nnewi, Nigeria.

F. O. Emelumadu, Nnamdi Azikiwe University Teaching Hospital Nnewi, Nigeria.

C. Ifeadike, Nnamdi Azikiwe University Teaching Hospital Nnewi, Nigeria.

M. J. Umeh, Nnamdi Azikiwe University Teaching Hospital Nnewi Nigeria.

C. E. Onah, Nnamdi Azikiwe University Teaching Hospital Nnewi, Nigeria.

A. Mbanuzuru, Nnamdi Azikiwe University Teaching Hospital Nnewi, Nigeria.

D. Obi, Nnamdi Azikiwe University Teaching Hospital Nnewi, Nigeria.

C. N. Ogbuagu, Nnamdi Azikiwe University Teaching Hospital Nnewi, Nigeria. health resulting in impaired cognition, kidney diseases, cardiovascular disorders and dysfunction in blood sugar regulation.

Index Terms - fluid intake; water-intake; high temperatures.

\section{BACKGROUND}

Water is essential for life [1] and a major constituent of the human body accounting for about 70 to 75 percent fatfree mass [2]. A person on daily basis loses about $700 \mathrm{ml}$ from insensible water loss, $1.6 \mathrm{~L}$ through bodily waste and $200 \mathrm{ml}$ in perspiration with normal, non- athletic activity. This means that just living and breathing in a temperate climate requires about $2.5 \mathrm{~L}$ a day [3]. Exercise and rises in ambient temperature increase perspiration, leading to additional loss of body water. Similarly, illness can also intensify the loose of body water.

Body water is maintained by balancing daily water intake with losses. The metabolic processes in the body produce about $250 \mathrm{ml}$ of water while about $750 \mathrm{ml}$ of water is obtained from the food that is eaten. The remaining $1.5 \mathrm{~L}$ is supplied from drinks [4], [5]. In order to maintain a balance, humans need to consume the same, or slightly more, fluid daily than is lost through perspiration, breathing, exercise and other functions.

The estimation of water requirement by the body is highly variable and quite complex. This is because a multitude of intra- and inter-individual factors like differences in metabolism, availability of water, level of activity, ambient temperature, flavour variety, beverage temperature and packaging, proximity of the beverage to the person etc. [2], [6]-[8]. As a result of the variability in water needs, adopting a uniform level is unacceptable but rather recommendations [2], [9], [10], have been made to be used as guide in the assessment and planning of diets for individuals and for groups.

The World Health Organization (WHO) recommends that under average conditions, a $70 \mathrm{~kg}$ adult male would require $2.5 \mathrm{~L}$ of water daily, while a $58 \mathrm{~kg}$ adult female would require $2.2 \mathrm{~L}$. Manual labour in high temperatures will increase the requirements to $4.5 \mathrm{~L}$ of water per day for both men and women. Recommendations for children are to be calculated using $1 \mathrm{~L}$ per day for a $10 \mathrm{~kg}$ child and $0.75 \mathrm{~L}$ per day for a $5 \mathrm{~kg}$ child [11]. On the other hand, the United States Institute of Medicine (IOM) recommends $2.7 \mathrm{~L} /$ day for adult women and $3.7 \mathrm{~L} /$ day for adult men [12], [13]. However, the WHO has also recommended that in setting local standards, local adjustments to the daily water consumption value may be needed in order to accommodate 
differences in water intake levels [14]. This is because daily direct and indirect water intake, water source, lifestyle, nutritional status and climate can significantly differ between countries.

This study assessed the fluid intake pattern in Anambra State and the factors that affect them.

\section{METHODS}

\section{A. Background of study area}

The study was conducted in Nnewi North and Awka South Local Government Areas (LGAs) of Anambra State, South East Nigeria. Awka South LGA is the Capital of Anambra State while Nnewi North LGA is the industrial base of the State. Awka South has a population of 189,654 while Nnewi North has a population of 155,443 according to the National population census of 2006 [15].

The State is located in the tropical rain forest with high temperatures and humidity in most months of the year except for brief period of cold dry winds associated with the hamattan season that occurs during parts of the dry season. The state lies in an undulating topography which is drained by the Omambala River (from which Anambra State derives its name). The predominant ethnic group is Igbo and Christianity is the prominent religion. The occupation of the people are farming, trading, civil service jobs and artisan.

The study was conducted in the hot dry season with high temperature and moderate humidity. The daily temperatures of Awka for January, February and March 2018 varied between $37{ }^{\circ} \mathrm{C}$ and $22{ }^{\circ} \mathrm{C}$ (January: $\max 37{ }^{\circ} \mathrm{C}$, average $28{ }^{\circ} \mathrm{C}$, min $22^{\circ} \mathrm{C}$, February $\max 37^{\circ} \mathrm{C}$, average $30^{\circ} \mathrm{C}$, min $25{ }^{\circ} \mathrm{C}$; March $\max 35^{\circ} \mathrm{C}$, average $29^{\circ} \mathrm{C}$, $\min 25^{\circ} \mathrm{C}$ ) while the atmospheric humidity were $32 \%, 57 \%$ and $67 \%$ for January, February and March respectively. The cloud cover for Awka were 6\%, 30\% and $46 \%$ for the months of January, February and March respectively [16]. The temperature values of Nnewi for the three months ranged from $22{ }^{\circ} \mathrm{C}$ to $36{ }^{\circ} \mathrm{C}$ (January: $\max 36{ }^{\circ} \mathrm{C}$, average $28{ }^{\circ} \mathrm{C}$, $\min 22^{\circ} \mathrm{C}$, February $\max 35^{\circ} \mathrm{C}$, average $29^{\circ} \mathrm{C}$, min $24^{\circ} \mathrm{C}$; March max $33{ }^{\circ} \mathrm{C}$, average $28{ }^{\circ} \mathrm{C}$, min $24{ }^{\circ} \mathrm{C}$ ). the atmospheric humidity were $42 \%, 64 \%$ and $73 \%$ for the months of January, February and March 2018 respectively. The cloud cover for Nnewi were $10 \%, 31 \%$ and $44 \%$ for the months of January, February and March respectively [17].

\section{B. Study Design}

A cross sectional study was carried out in Anambra State to assess the fluid intake of adults and the factors associated with it.

\section{Study population}

The study population were representatives of the major occupations operating in the state i.e. office workers employed by government and artisans engaged in motor mechanic works. They were drawn from the civil servants working in the State and Local Government secretariats and banks and motor mechanic workers in the two selected towns. The motor mechanics work with minimal equipment (non-mechanized) and operate mostly in open spaces without shades except occasionally under tree shades or the covers provided by the vehicles they are servicing.

\section{1. Inclusion criteria}

Civil servants engaged in the state/local government or bank workers who are willing to participate in the study. The motor mechanic workers in the two cities who are willing to participate in the study.

\section{2. Exclusion criteria}

Subjects that met the criteria above but have acute medical conditions at the time of the study or absenting from normal physical activities or dietary restrictions e.g. fasting. The study was conducted during the week days to avoid drinking spree and festive activities associated with the weekends.

\section{Sample size determination}

Required sample size was calculated by using the formula for cross sectional study for estimating a quantitative variable (mean value in this case) [18].

$$
n=\frac{\mathrm{Z}^{2} \cdot \mathrm{SD}^{2}}{\mathrm{~d}^{2}} \text {, }
$$

where,

$n$ - estimated sample size;

$Z$ - Standard Normal Variate (at $5 \%$ type 1 error $(\mathrm{P} \leq 0.05)$ is 1.96;

SD - Standard deviation (standard error) of variable, equals 19 (the mean total water intake from all source for US adult population is $3311 \pm 19 \mathrm{~mL}$ ) [13];

$\mathrm{d}$ - Absolute error or precision set for the study.

The estimated sample size is:

$$
n=\frac{1.96^{2} \cdot 19^{2}}{2.5^{2}}=222
$$

This is approximated to 250 subjects.

\section{E. Sampling technique}

A multi-stage sampling technique was used for the selection of the subjects. The first phase of the sampling was the selection of two towns from two of the three senatorial districts of Anambra State; Awka South for Anambra Central Senatorial District and Nnewi North from Anambra South Senatorial District. In each of the two selected towns, a cluster sampling technique was used to select groups of workers - artisans and civil servants.

The clusters selected for the civil servants in Nnewi were Local Government secretariat and two banks while the clusters selected for Awka South LGA were ministries in the State secretariat. For the manual workers' group, three motor mechanic settlements were selected in Nnewi and three in Awka. In each selected clusters, subjects were recruited till the required number of people were obtained.

\section{F. Study instruments}

The study instruments comprise of the following:

1. Questionnaires (quantitative) to collect sociodemographic data of subjects and fluid intake diary.

2. Anthropometric measuring instruments - weighing scale for weight measurement, standiometer for height.

Calibrated plastic cups for assessment of 24-hour fluid intake.

\section{F 1. Pretesting}

The research instrument was pretested among civil 
servants and the (artisans) motor mechanics in Anaocha LGA and Dunukofia LGA in Anambra State. The findings were used to refine the research instrument and procedures.

\section{G. Data Collection Methods}

Questionnaires were administered to the subjects and relevant data obtained from them; socio-demographic data, age, sex, education, marital status, occupation, etc. Weight and height measurements were conducted by trained assistants (medical doctors undergoing specialist trained in public health) with necessary measures for reliability and standardization of records taken in order to reduce bias.

Subjects were tutored on how to assess the quantities of water and other liquids they drank and were issued calibrated plastic cups. They were taught on how to measure and estimate their fluid intake and record same for a 24-hour period. This was conducted by a seasoned Nutritionist to ensure proper measurements/assessments and documentation. The subjects thereafter provided information on their fluid intake in the last 24 hours (Total Fluid Intake Recall - Pre-survey Day data on fluid intake).

Survey Day 1 data: Quantitative survey on sociodemographic variables, and anthropometric measurement on survey day.

Second Day 2 data: Fluid intake assessed following the issue of cups to subjects - (24-hour Total Fluid Intake Assessed). The subjects provided information on their 24hour fluid intake using the calibrated plastic cups they were issued. The fluid assessed included - water, fruit/vegetable juice, milk, yoghurt, tea, coffee, alcohol, soft drinks, herbal drinks, energy drinks, pepper soups etc.

The participants in the study were not paid but they were given the opportunity to have their physiological parameters measured (blood pressure, body weight and height and were also provided general health education on wellbeing, diet, exercise and utilization of health care services.

\section{H. Data Management}

Data analysis was done using IBM Statistical Package for the Social Sciences (SPSS) software version 21. Descriptive statistical data (percentages, mean, median, standard deviations) were obtained for the independent and outcome variables for the study population.

Comparisons of the fluid intake of the subjects were made with values of WHO and USA IOM recommendations for $70 \mathrm{~kg}$ adult males, $58 \mathrm{~kg}$ adult females, people on moderate activities and manual labour under high temperatures.

\section{Ethical considerations}

Ethical clearance was sought and obtained from the Nnamdi Azikiwe University Teaching Hospital Ethical Committee (NAUTHEC). A verbal informed consent was obtained from the participants after a detailed explanation of the procedures involved.

All aspects of the data collection process were noninvasive procedures. Confidentiality was assured to the participants and they were informed that they were at liberty to withdraw at any stage of the study without any repercussion associated with the withdrawal.

\section{RESULTS}

\section{A. Socio-Demographic Variables}

The mean age of the respondents was $36.6 \pm 11.5$ years. $60.1 \%$ (146) were males while $39.9 \%$ (97) were females.

$55.6 \%$ (135) of the subjects were married, $42 \%$ (102) were single, while the remaining $1.6 \%$ (4) were separated, divorced or widowed.

$42 \%$ (102) of the subjects had tertiary education, 37\% (90) had secondary education, $18.9 \%$ (46) had primary while $0.4 \%$ (1) had no formal education.

There were $130(53.5 \%)$ civil servants and $113(46.5 \%)$ artisans (motor mechanics). The mean Body Mass Index (BMI) of the subjects was $26.42 \pm 4.7 \mathrm{~kg} / \mathrm{m}^{2}$. The median body mass index (BMI) was $25.8 \mathrm{Kg} / \mathrm{M} 2$. Only $1.6 \%$ (4) of the subjects had BMI of less than $18.5 \mathrm{~kg} / \mathrm{m}^{2}, 41.2 \%$ had normal BMI $(18.5-24.9 \mathrm{Kg} / \mathrm{M} 2), 35 \%$ were overweight $\left(25-29.9 \mathrm{~kg} / \mathrm{m}^{2}\right), \quad 17.3 \%$ were Obesity class 1 (30$\left.34.9 \mathrm{~kg} / \mathrm{m}^{2}\right)$ and $4.9 \%$ were Obesity Class $2\left(35-39 \mathrm{~kg} / \mathrm{m}^{2}\right)-$ Table I.

\begin{tabular}{|c|c|c|c|}
\hline $\mathrm{S} /$ & \multicolumn{2}{|c|}{ Socio-demographic variables } & Descriptive statistics \\
\hline 1 & \multicolumn{2}{|l|}{ Age (years) } & $36.6 \pm 11.5 \mathrm{~s}$ \\
\hline \multirow[t]{2}{*}{2} & \multirow[t]{2}{*}{ Sex } & Males & $60.1 \%(146)$ \\
\hline & & Females & $39.9 \%(97)$ \\
\hline \multirow[t]{3}{*}{3} & \multirow{3}{*}{$\begin{array}{l}\text { Marital } \\
\text { status }\end{array}$} & Married & $55.6 \%(135)$ \\
\hline & & Single & $42 \%(102)$ \\
\hline & & $\begin{array}{l}\text { Separated, divorced } \\
\text { /widowed }\end{array}$ & $1.6 \%(4)$ \\
\hline \multirow[t]{4}{*}{4} & \multirow[t]{4}{*}{$\begin{array}{l}\text { Educational } \\
\text { status }\end{array}$} & $\begin{array}{l}\text { No formal } \\
\text { Education }\end{array}$ & $0.4 \%(1)$ \\
\hline & & Primary & $18.9 \%(46)$ \\
\hline & & Secondary & $37 \%(90)$ \\
\hline & & Tertiary & $42 \%(102)$ \\
\hline \multirow[t]{2}{*}{5} & \multirow[t]{2}{*}{ occupations } & $\begin{array}{l}\text { Civil servants } \\
\text { (office workers) }\end{array}$ & $53.5 \%(130)$ \\
\hline & & $\begin{array}{l}\text { Artisans (motor } \\
\text { mechanics). }\end{array}$ & $46.5 \%(113)$ \\
\hline \multirow[t]{7}{*}{6} & \multirow{7}{*}{$\begin{array}{l}\text { Body Mass } \\
\text { Index } \\
\left(\mathrm{kg} / \mathrm{m}^{2}\right)\end{array}$} & Underweight & $1.6 \%(4)$ \\
\hline & & Normal BMI & $41.2 \%$ \\
\hline & & Overweight & $35 \%$ \\
\hline & & Obesity class 1 & $17.3 \%$ \\
\hline & & Obesity class 2 & $4.9 \%$ \\
\hline & & Mean BMI. & $26.42 \pm 4.7$ \\
\hline & & Median BMI & 25.8 \\
\hline
\end{tabular}

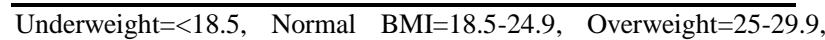
Obesity class $1=30-34.9$, Obesity class $2=35-39 \mathrm{~kg} / \mathrm{m}^{2}$.

\section{B. Total Fluid Intake Of Subjects}

The mean total fluid intake recall (for 24 hours) for the day before the survey was $3.46 \pm 1.7 \mathrm{~L}$ and a median of 3.2 L. The mean total fluid intake assessed for 24 hours following the provision of the calibrated cups was $3.78 \pm 3.1 \mathrm{~L}$ with a median of $3.5 \mathrm{~L}$ (Table II). The value obtained on the Day 1 of the survey based on the assessment of the fluid intake measured by the subjects using the calibrated cups is accepted as the most appropriate measure of fluid intake. (The skewness of the data distribution (fluid 
intake assessed) is 9.967 and kurtosis 130.909). The median value of the total fluid intake assessed is therefore taken as the preferred 24-hour fluid intake of the subjects.

TABLE II: DISTRIBUTION OF TOTAL FLUID INTAKE OF SUBJECTS

\begin{tabular}{ccccc}
\multicolumn{5}{c}{ ACCORDING TO SEX } \\
\hline \multirow{2}{*}{$\mathrm{S} /$} & Fluid & \multicolumn{3}{c}{ Frequency and Cumulative Frequency } \\
$\mathrm{N}$ & Intake & \multicolumn{3}{c}{ (Cumulative) } \\
\cline { 3 - 5 } & $(\mathrm{mL})$ & Male & Female & ALL Subjects \\
\multirow{2}{*}{1} & $300-$ & $1.4 \%$ & $5.2 \%$ & $2.9 \%$ \\
& 1499 & $(1.4 \%)$ & $(5.2 \%)$ & $(2.9 \%)$ \\
\multirow{2}{*}{2} & $1500-$ & $6.2 \%$ & $10.3 \%$ & $7.9 \%$ \\
& 1999 & $(7.6 \%)$ & $(15.5 \%)$ & $(10.8 \%)$ \\
\multirow{2}{*}{3} & $2000-$ & $3.5 \%$ & $6.1 \%$ & $4.6 \%$ \\
& 2199 & $(11.1 \%)$ & $(21.6 \%)$ & $(15.4 \%)$ \\
4 & $2200-$ & $6.3 \%$ & $12.4 \%$ & $8.7 \%$ \\
& 2499 & $(17.4 \%)$ & $(34.0 \%)$ & $(24.1 \%)$ \\
5 & $2500-$ & $5.5 \%$ & $5.2 \%$ & $5.4 \%$ \\
& 2699 & $(22.9 \%)$ & $(39.2 \%)$ & $(29.5 \%)$ \\
6 & $2700-$ & $4.2 \%$ & $6.2 \%$ & $4.9 \%$ \\
& 2999 & $(27.1 \%)$ & $(45.4 \%)$ & $(34.4 \%)$ \\
7 & $3000-$ & $11.1 \%$ & $16.5 \%$ & 13.3 \\
& 3499 & $(38.2 \%)$ & $(61.9 \%)$ & $(47.7 \%)$ \\
\multirow{2}{*}{8} & $3500-$ & $9.7 \%$ & $6.1 \%$ & 8.3 \\
& 3699 & $(47.9 \%)$ & $(68.0 \%)$ & $(56.0 \%)$ \\
9 & $3700-$ & $22.2 \%$ & 14.5 & 19.1 \\
& 4499 & $(70.1 \%)$ & $(82.5 \%)$ & $(75.1 \%)$ \\
& $4500-$ & $29.9 \%$ & $17.5 \%$ & 24.9 \\
& 9000 & $(100 \%)$ & $(100 \%)$ & $(100 \%)$ \\
\hline
\end{tabular}

The values in parenthesis are cumulative frequencies.

The ranges used in the fluid intake were taken to capture the various recommendations set by WHO and USA IOM for males and females in normal conditions and in high temperatures.

\section{Fluid Intake and socio-demographic variables}

There is no statistical association between total fluid intake and age of subjects, $\left(\chi^{2}=1.6635, \mathrm{df}=6, \mathrm{p}>0.05\right)$, educational status of subjects, $\left(\chi^{2}=6.581, \mathrm{df}=6, \mathrm{p}>0.05\right)$ and marital status $\left(\chi^{2}=0.121, \mathrm{df}=2, \mathrm{p}>0.05\right)$. There is statistical association between the occupational status of the subjects and total fluid intake $\left(\chi^{2}=16.57, \mathrm{df}=2, \mathrm{p}<0.05\right)$ with the artisans having higher proportions of subjects $(64.6 \%)$ of those who drank $3.5 \mathrm{~L}$ and above compared with $39.2 \%$ of civil servants who drank $3.5 \mathrm{~L}$ and above (Table III).

TABLE III: RELATIONSHIP BETWEEN SOCIO-DEMOGRAPHIC VARIABLES, BMI AND TOTAL FLUID INTAKE

\begin{tabular}{|c|c|c|c|c|c|}
\hline $\begin{array}{l}\mathrm{S} / \\
\mathrm{N}\end{array}$ & $\begin{array}{l}\text { Socio- } \\
\text { demographic } \\
\text { variable }\end{array}$ & $\begin{array}{l}\text { Statistical } \\
\text { test }\end{array}$ & value & $\mathrm{p}$ value & Remark \\
\hline 1 & Age & $\chi^{2}$ & $\begin{array}{l}1.6635 \\
(\mathrm{df}=6)\end{array}$ & $p>0.05$ & $\begin{array}{l}\text { No } \\
\text { statistical } \\
\text { significance }\end{array}$ \\
\hline 2 & $\begin{array}{l}\text { Educational } \\
\text { status }\end{array}$ & $\chi^{2}$ & $\begin{array}{l}6.581 \\
(\mathrm{df}=6)\end{array}$ & $\mathrm{p}>0.05$ & $\begin{array}{l}\text { No } \\
\text { statistical } \\
\text { significance }\end{array}$ \\
\hline 3 & $\begin{array}{l}\text { Occupational } \\
\text { status }\end{array}$ & $\chi^{2}$ & $\begin{array}{l}16.57, \\
(\mathrm{df}=2)\end{array}$ & $\mathrm{p}<0.05$ & $\begin{array}{l}\text { There is } \\
\text { statistical } \\
\text { significance }\end{array}$ \\
\hline 4 & Marital status & $\chi^{2}$ & $\begin{array}{l}0.121, \\
(\mathrm{df}=2)\end{array}$ & $p>0.05$ & $\begin{array}{l}\text { No } \\
\text { statistical } \\
\text { significance }\end{array}$ \\
\hline 5 & Sex & $\mathrm{Z}$ & 4.14147 & $\mathrm{P}<0.05$ & $\begin{array}{l}\text { There is } \\
\text { statistical } \\
\text { significance }\end{array}$ \\
\hline 6 & BMI & $\chi^{2}$ & $\begin{array}{l}3.388, \\
(\mathrm{df}=4)\end{array}$ & $\mathrm{p}>0.05$ & $\begin{array}{l}\text { No } \\
\text { statistical } \\
\text { significance }\end{array}$ \\
\hline
\end{tabular}

No statistical association was established between the total fluid intake and the Body Mass Index of the subjects $\left(\chi^{2}=3.388, \mathrm{df}=4, \mathrm{p}>0.05\right)$.

\section{Fluid Intake by sex}

The mean total fluid intake for males was $4.2 \pm 3.7 \mathrm{~L}$ and median is $3.8 \mathrm{~L}$.

About one sixth (17.4\%) of the male subjects drank less than the $2.5 \mathrm{~L}$ recommended by the WHO for males.

The mean total fluid intake for females was $3.2 \pm 1.4 \mathrm{~L}$ and median 3.1 L.

About one fifth $(21.6 \%)$ of the females drank less than the $2.2 \mathrm{~L}$ per day recommended for females by the WHO. There is statistical difference between the fluid intakes of males and females $(\mathrm{Z}=4.14147, \mathrm{p}<0.05)$.

\section{E. Fluid Intake by sex in moderate activities and high temperatures}

Fifty six percent $(56 \%)$ of the subjects drank less than the 3.7 L of fluid recommended by the WHO for people engaged in moderate activities. On the other hand, $75.1 \%$ of the subjects drank less than $4.5 \mathrm{~L}$ which is the recommended value for persons engaged in manual labour in high temperatures.

About $48 \%$ (47.9\%) of males drank less than $3.7 \mathrm{~L}$ for moderate activity and $70.1 \%$ drank less than $4.5 \mathrm{~L}$ for manual labour in high temperatures. On the other hand, $68 \%$ of the females drank less than the $3.7 \mathrm{~L}$ for moderate activity and $82.5 \%$ drank less than $4.5 \mathrm{~L}$ for manual labour in high temperatures.

\section{DISCUSSION}

Hydration involves a dynamic balance between water intake and loss and is maintained through both behavioral and physiological responses. Water gains come almost entirely from fluids and water in food, as metabolic water accounts for only a small fraction of daily water gain [19]. The study is focused on the total fluid intake by subjects in the form of water, beverages including alcohol, juices etc.

The mean Total Fluid intake obtained a day befor the survey (recall) was $3.46 \pm 1.7 \mathrm{~L}$ and a median of $3.2 \mathrm{~L}$. The mean Total fluid Intake assessed for 24 hours following the provision of the calibrated cups was $3.78 \pm 3.1 \mathrm{~L}$ with a median of $3.5 \mathrm{~L}$. The total fluid Intake assessed using the calibrated cups is taken as the preferred 24 hour fluid intake of the subjects. Since the data is skewed (skewness 9.967 and kurtosis 130.909), the median in this study is accepted as a preferred measure of central tendency $(3.5 \mathrm{~L})$.

The age of the subjects, educational status, marital status were not statistically associated with the total fluid Intake. The ages of the subjects studied were in the active working population mostly between 18 and 60 years with small proportion of people between 60 and 65 years $(2.1 \%)$. This may explain the non differences in water intake between the ages. However, Adam et al, found association with age, race and social class [18]. Other studies among elderly and institutional subjects have found associations between ages and fluid intakes [20-22].

The subjects studied consumed less quantities of fluid compared with recognized standards set by the World 
Health Organization (WHO) [11] and the United States Institute of Medicine (IOM) [12] as $17.4 \%$ of the males drank less than the $2.5 \mathrm{~L}$ recommended by the WHO while $21.6 \%$ of the females drank less than the $2.2 \mathrm{~L}$ recommended for females. High percentages of the males $(47.9 \%)$ and females $(39.2 \%)$ failed to meet the $3.7 \mathrm{~L} /$ day for adult men and $2.7 \mathrm{~mL} /$ day for adult women recommended by the IOM [12].

For American adults 20-50 years $42.7 \%$ of men and $40.6 \%$ of women failed to meet the IOM adequate intake value for total water $(3700 \mathrm{~mL}$ for men and $2700 \mathrm{~mL}$ for women) [12]-[13]. This is indicative that people tend to generally drink less than recommended fluid levels. However, the study population in the current investigation were made of $46.5 \%$ of artisan workers and $53.5 \%$ of office workers operating under high temperatures $\left(35{ }^{\circ} \mathrm{C}\right.$ and $37^{\circ} \mathrm{C}$ ) for whom the WHO recommended a daily fluid intake of $4.5 \mathrm{~L}$, yet their fluid intake still lag behind (or for females equate to) that of the Americans who live in temperate climate. A number of factors have been recognized to influence fluid intake such as physiologic responses, sensations, preferences, cultural influences, learned behaviors, fluid characteristics, and environmental factors [23]-[28]. Some of these may account for the observed lower quantities of fluid in this study.

Conventionally, people who work or exercise in high temperatures are encouraged to ingest extra volumes of fluid in order to maintain the body's homoeostatic mechanism and avert impaired work/exercise performance or endanger health [29]-[30]. High fluid intake is also encouraged to maintain good performance, cognition, avert health conditions such as kidney stone formation, chronic kidney disease, cardiovascular disorders and sustain blood sugar regulation [31]-[37].

The study showed that substantial proportion of the population drank less quantities of water than people in temperate climate and also below the recommendadtions of both the WHO and the USA IOM despite operating under high temperatures.

\section{COMPETING INTERESTS}

There is no competing interest as the study was not sponsored by any external body and non of the investigators is engaged in any water, beverage or other related business that the study findings may promote their interests.

\section{ACKNOWLEDGEMENTS AND FUNDING}

We hereby acknowledge the sacrifices of the Resident doctors of the Department of Community Medicine, Nnamdi Azikiwe Uniersity Teaching Hospital Nnewi, Anambra State, Nigeria, the leadership of the Motor Mechanic Association and that of the Anambra State Ministries and the Nnewi North Local Government for their collaboration in the conduct of the study.

\section{REFERENCES}

[1] E. Jéquier and F. Constant, Water as an essential nutrient: the physiological basis of hydration. Eur J Clin Nutr, vol. 64, pp. 115123, Feb. 2010.

[2] Food and Nutrition Board, Institute of Medicine. Dietary Reference Intakes For Water, Potassium, Sodium, Chloride, And Sulfate. National Academies Press, Washington, DC, 2005, pp. 74-75.

[3] A.C. Grandjean, Water requirements, impinging factors, and recommended intakes. The Centre for Human Nutrition, University of Nebraska Omaha, Nebraska- USA, 2009, pp. 25 - 40. Availlable: https://www.slideshare.net/dhaupu/nutrientschap3.

[4] Metabolic Water. Saunders Comprehensive Veterinary Dictionary, 3rd ed; Elsevier Inc, 2007.

[5] S. M. Shirreffs. The importance of good hydration for work and exercise performance. Nutrition Reviews, vol. 63,S pp. 14-21, 2005.

[6] T. Westrell, Y. Andersson and T.A. Stenström, Drinking water consumption patterns in Sweden, J Water Health, vol.4, no. 4, 511-22. Dec. 2006.

[7] A. C. Grandjean, K. J. Reimers, M. C. Haven and G. L. Curtis, The effect on hydration of two diets, one with and one without plain water. JACN, vol, 22, no. 2 pp. 165-173, 2003.

[8] A. C. Grandjean, K. J. Reimers, K. E. Bannick and Haven MC, The effect of caffeinated, non-caffeinated, caloric and non-caloric beverages on hydration. JACN, vol. 19, no. 5, pp. 591-600, 2000.

[9] U.S. Environmental Protection Agency. Estimated Per Capita Water Ingestion In The United States - an update based on data collected by the U.S. Department of Agriculture's 1994-1997 and 1998 Continuing Survey of Food Intakes by Individuals. Washington, DC: U.S Environmental Protection Agency, EPA/822/R-00/001, 2004.

[10] M. N. Sawka and S. J. Montain, Fluid and electrolyte balance: effects on thermoregulation and exercise in the heat. In: B. A. Bowman and R. M. Russell, editors. Present Knowledge in Nutrition, Washington, DC: ILSI Press, 2001, pp. 115-124.

[11] G. Howard and J. Bartram, Domestic Water Quantity, Service, Level And Health. World Health Organization, Ref Type: Report, 2003.

[12] Food and Nutrition Board, Institute of Medicine. Dietary Reference Intakes For Water, Potassium, Sodium, Chloride, And Sulfate. Washington, D.C.: National Academies Press, 2005, ch. 4, pp. 140 47.

[13] A. Drewnowski, C. D. Rehm and F. Constant. Water and beverage consumption among adults in the United States: Cross-sectional study using data from NHANES 2005-2010. BMC Public Health, vol. 13 1068, 2013

[14] World Health Organization. Guidelines For Drinking-Water Quality. 4th ed. Geneva: World Health Organization, 2011, 164-8.

[15] National Population Commission, Abuja Nigeria, Population Distribution By Sex, State, LGAs and Senatorial District, 2006 Census Priority Tables, 2006, vol. 3.

[16] Awka Monthly Climate Averages, Anambra, NG. Available: https://www.worldweatheronline.com/awka-weatheraverages/anambra/ng.aspx.

[17] Nnewi Monthly Climate Averages, Anambra, NG. Available: https://www.worldweatheronline.com/nnewi-weatheraverages/anambra/ng.aspx

[18] J. Charan and T. Biswas. How to calculate sample size for different study designs in medical research? Indian J Psychol Med, vol. 35, no. 2, 121-126, Apr-Jun 2013.

[19] E. T. Perrier, I. Buendia-Jimenez, M. Vecchio, L. E. Armstrong, I. Tack and A. Klein. Twenty-four-hour urine osmolality as a physiological index of adequate water intake. Dis Markers, 2015: 231063.

Available: https://www.hindawi.com/journals/dm/2015/231063/

[20] J. L. Warren, W. E. Bacon, T. Harris, A. M. McBean, D. J. Foley and C. Phillips, The burden and outcomes associated with dehydration among US elderly, 1991. Am J Public Health, vol. 84, no. 8, pp. 1265-1269, 1994

[21] J. Dimant, Delivery of nutrition and hydration care in nursing homes: assessment and interventions to prevent and treat dehydration, malnutrition, and weight loss, J Am Med Dir Assoc, vol. 2, no. 4, pp. 175-182, 2001.

[22] S. Hamilton, Detecting dehydration and malnutrition in the elderly, Nursing (Lond), vol. 31(12):56-57, 2001.

[23] Greenleaf JE. Problem: thirst, drinking behavior, and involuntary dehydration. Med Sci Sports Exerc. 1992;24(6):645-656.

[24] Johnson AK. The sensory psychobiology of thirst and salt appetite. Med Sci Sports Exerc. 2007;39(8):1388-1400.

[25] Pross N., Demazières A., Girard N., Barnouin R., Metzger D., Klein A., Perrier E., Guelinckx I. Effects of changes in water intake on 
mood of high and low drinkers. PLoS ONE. 2014;9:e94754. doi: 10.1371/journal.pone.0094754.

[26] Johnson E.C., Muñoz C.X., Jimenez L., Le Bellego L., Kupchak B.R., Kraemer W.J., Casa D.J., Maresh C.M., Armstrong L.E. Hormonal and thirst modulated maintenance of fluid balance in young women with different levels of habitual fluid consumption. Nutrients 2016;8:302. doi: 10.3390/nu8050302.

[27] Maughan R.J., Watson P., Cordery P.A., Walsh N.P., Oliver S.J., Dolci A., Rodriguez-Sanchez N., Galloway S.D. A randomized trial to assess the potential of different beverages to affect hydration status: Development of a beverage hydration index. Am. J. Clin. Nutr. 2016;103:717-723.

[28] Stookey J.D., Hamer J., Killilea D.W. Change in hydration indices associated with an increase in total water intake of more than 0.5 L/day, sustained over 4 weeks, in healthy young men with initial total water intake below 2 L/day. Physiol. Rep. 2017.

[29] R J Maughan, J B Leiper, S M Shirreffs. Factors influencing the restoration of fluid and electrolyte balance after exercise in the heat BrJ Spors Med 1997;31:175-182

[30] Lawrence E. Armstrong, Evan C. Johnson, Laura J. Kunces, Matthew S. Ganio, Daniel A. Judelson, Brian R. Kupchak, Jakob L. Vingren, CSCS, Colleen X. Munoz, Robert A. Huggins, Jay R. Hydren, Nicole E. Moyen, Keith H. Williamson. Drinking to Thirst Versus Drinking Ad Libitum During Road Cycling. J Athl Train. 2014 Sep-Oct; 49(5): 624-631.

[31] G. C. Curhan, W. C. Willett, E. L. Knight, and M. J. Stampfer, "Dietary factors and the risk of incident kidney stones in younger women: Nurses' Health study II," Archives of Internal Medicine, vol. 164 , no. 8, pp. 885-891, 2004.

[32] M. Dai, A. Zhao, A. Liu, L. You, and P. Wang, "Dietary factors and risk of kidney stone: a case-control study in southern China," Journal of Renal Nutrition, vol. 23, no. 2, pp. e21-e28, 2013.

[33] M. D. Sorensen, A. J. Kahn, A. P. Reiner et al., "Impact of nutritional factors on incident kidney stone formation: a report from the WHI OS," Journal of Urology, vol. 187, no. 5, pp. 1645-1649, 2012.

[34] W. F. Clark, J. M. Sontrop, J. J. Macnab et al., "Urine volume and change in estimated GFR in a community-based cohort study," Clinical Journal of the American Society of Nephrology, vol. 6, no. 11, pp. 2634-2641, 2011.

[35] J. M. Sontrop, S. N. Dixon, A. X. Garg et al., "Association between water intake, chronic kidney disease, and cardiovascular disease: a cross-sectional analysis of NHANES data," The American Journal of Nephrology, vol. 37, no. 5, pp. 434-442, 2013.

[36] G. F. M. Strippoli, J. C. Craig, E. Rochtchina, V. M. Flood, J. J. Wang, and P. Mitchell, "Fluid and nutrient intake and risk of chronic kidney disease," Nephrology (Carlton), vol. 16, no. 3, pp. 326-334, 2011.

[37] R. Roussel, L. Fezeu, N. Bouby et al., "Low water intake and risk for new-onset hyperglycemia," Diabetes Care, vol. 34 , no. 12, pp. 2551 $2554,2011$.

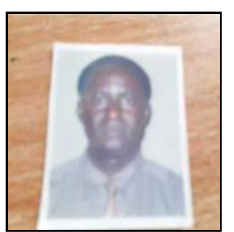

Prof. Christian C. Ibeh.

MBBS, UNN 1987, FWACP 1994, Diploma Health System Management Galilee College Israel 2006. Consultant Public Health Physician, NAUTH Nnewi/Academic staff, CHS NAU Awka, Nigeria. Professional Associations - NMA, MDCAN, APHPN, EPISON, IEA.

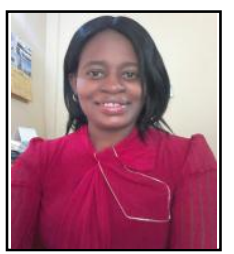

Dr Jisieike Onuigbo Nonyelum Nnenna.

MBBS 1997, NAU Awka, FMCP 2008, NAUTH

Consultant Physician/Senior Lecturer Nephrology Unit, Internal Medicine, NAUTH Nnewi/ NAU Awka, Membership of Associations - NMA, MDCAN, International Society of Nephrology (ISN), Nigerian Association of Nephrology (NAN).

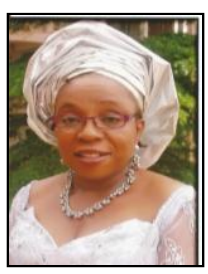

Prof. Emelumadu Obiageli Fidelia.

MBBS UNN 1981, DTM \&H Liverpool, UK 1983 FWACP (2004).

Consultant Public Health Physician, NAUTH Nnewi and academic staff CHS NAU Awka, Nigeria. Membership of Associations - NMA, MWAN, MDCAN, APHPN, EPISON, IEA, SPHPN.
Prof. Chigozie Ozoemena Ifeadike.

MBBS NAU 1996, FMCPH 2007.

Consultant Public Health Physician, NAUTH Nnewi and academic staff CHS NAU Awka, Nigeria. Membership of Associations - NMA, MWAN, MDCAN, APHPN, EPISON, IEA

\section{Mary Jane Umeh.}

BSc, Nutrition and Dietetics, The University of Texas School of Allied Health Sciences 1983, MSc Clinical Nutrition, Texas Woman's University, Houston 1986

Registered with American with American Dietetic Association (ADA) 1985. Former Head of Dept, Dietetics Department, NAUTH Nnewi, Anambra State, Nigeria.

\section{Dr Christian Ejike Onah.}

BSc Medical Laboratory Science UNN 2006, MSc Chemical Pathology, NAU Awka, 2011, PhD Chemical Pathology NAU Awka 2018.

Principal Medical Laboratory Scientist, NAUTH, Lecturer CHS NAU Awka, Nigeria

Published over 35 peer reviewed papers in international journals

Membership of Associations: Medical Laboratory Science Council of Nigeria, Association of Clinical Chemists of Nigeria.

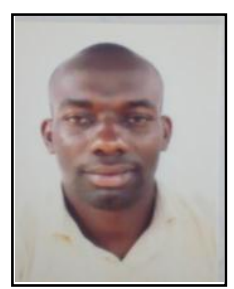

Dr Ahoma Victor Mbanuzuru.

MBBS UNN 2008, FWACP 2019, FMCPH 2019. MSc Statistics NAU (in-view).

Published articles in peer reviewed professional journals. Membership of Associations: IEA, EPSON and APHPN

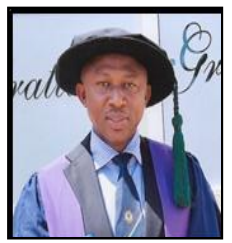

Dr Darlington C. Obi

MBBS, MPH, FWACP 2019, Consultant Physician NAUTH Nnewi, Lecturer CHS NAU Awka, Anambra State, Nigeria. Formerly Anambra State Co-ordinator Routine Immunization Lot Quality Assurance Sampling Survey. Published articles both in local and international academic journals. EPSON, APHPN/ Membership of Associations: NMA, MDCAN, IEA,

\section{Dr Chukwuanugo Nkemakonam Ogbuagu}

BSc Parasitology/ Entomology 1998 NAU, MBBS 2005 NAU Awka. MSc Public Health Parasitology 2008, NAU Awka, PhD Public Health Parasitology 2016, NAU Awka, Nigeria.

Principal Medical Officer NAUTH Nnewi, Nigeria. EDCTP scholarship recipient Lisbon Portugal 2018 on Neglected Diseases of Poverty (NDP) Research. WHO/TDR certified Implementation researcher. 